\title{
Expression of betaglycan in pregnant tissues throughout gestation
}

Pasquapina Ciarmela, Pasquale Florio, Paolo Toti ${ }^{1}$, Daniela Grasso, Rosa Santopietro ${ }^{1}$, Piero Tosi $^{1}$ and Felice Petraglia

Obstetrics and Gynaecology Unit, Department of Paediatrics, Obstetrics and Reproductive Medicine and ${ }^{1}$ Department of Human Pathology and Oncology, University of Siena, Siena, Italy

(Correspondence should be addressed to Felice Petraglia, Department of Paediatrics, Obstetrics and Reproductive Medicine, University of Siena, Policlinico 'Le Scotte', viale Bracci, 53100 Siena, Italy; Email: petraglia@unisi.it)

\begin{abstract}
Background: Betaglycan is a membrane-anchored proteoglycan involved in mediating the passage of transforming growth factor- $\beta$ (TGF- $\beta$ ), inhibin and activin activities into cells. TGF- $\beta$ and inhibin-related proteins are growth factors that are expressed by several tissues and in pregnancy. They have a function in modulating the growth, differentiation and invasion of the placental trophoblast.

Objective: To evaluate whether betaglycan is expressed by intrauterine tissues throughout gestation. Design and methods: Expression of betaglycan mRNA and protein was evaluated (by RT-PCR and immunohistochemistry, respectively) in trophoblast, decidua and fetal membranes collected during the first ( $n=6$ elective terminations of pregnancy, between 8 and 12 gestational weeks) and third ( $n=6$ elective caesarean sections, between 39 and 40 weeks) trimesters of pregnancy.

Results: Betaglycan mRNA was expressed by all gestational tissues, independently of gestational age. Immunoreactive protein was found in decidual cells and in some chorionic, but not epithelial, amniotic cells. With respect to the placental localization, syncytiotrophoblast, but not cytotrophoblast, cells were intensively stained both in the placental bed and in the villous trophoblast, and in some cells within the stroma of terminal villi, of the first and third trimesters of pregnancy. Immunoreactive betaglycan was demonstrated in the endothelial cells of decidual vessels in both the first and third trimesters of pregnancy, whereas endothelial cells of fetal blood vessels in the villous were clearly represented only in first trimester samples, not in those of term placenta.

Conclusions: Betaglycan mRNA and peptide are expressed by the trophoblast, the decidua and the fetal membranes, but the localization of the peptide in vessel walls is dependent on gestational age.
\end{abstract}

European Journal of Endocrinology 149 433-437

\section{Introduction}

Betaglycan is a membrane-anchored proteoglycan that is involved in mediating the passage of transforming growth factor- $\beta$ (TGF- $\beta$ ), inhibin $A$ and activin $A$ activities into cells (1) and therefore has an essential role in their signalling. In fact, betaglycan works as TGF- $\beta$ receptor type III (TGF- $\beta$ RIII), as it binds TGF- $\beta$; depending on the cell type, it prevents or stimulates the association of TGF- $\beta$ R type II (TGF- $\beta$ RII) with type I (TGF- $\beta R I)$ (2). Betaglycan is also involved in the inhibin A pathway, as it facilitates the binding of inhibin $A$ to the activin receptor type II (ActRII), allowing the formation of a ternary complex including inhibin A, betaglycan and ActRII that is involved in the transduction of the inhibin A pathway into the cells. Finally, betaglycan also interacts with activin A, preventing the binding of activin A to ActRII and thereby antagonizing the activin signal $(1,3)$.

TGF- $\beta$, inhibin $A$ and activin $A$ are growth factors that are expressed by the placenta (4), where they have essential functions in modulating the growth, differentiation and invasion of the placental trophoblast, and placental hormonogenesis $(4-6)$. In the light of all this evidence, the present study was undertaken to evaluate the expression of betaglycan in first and third trimester placenta, decidua and fetal membranes.

\section{Materials and methods}

Specimens of human placenta, maternal decidua and fetal membranes were collected from pregnant women who underwent elective termination of pregnancy 
( $n=6$; gestational age between 8 and 12 weeks) and elective caesarean section $(n=6$; between 38 and 40 gestational weeks). Gestational age was calculated on the basis of the last menstrual period and confirmed by ultrasound evaluation. Informed written consent was obtained from all patients before their inclusion in the study, for which approval was obtained from the local Human Investigation Committee.

The specimens collected were subdivided into aliquots for RT-PCR (samples were immediately frozen in liquid nitrogen for extraction of total RNA) and immunohistochemistry (samples were fixed by immersion in $10 \%$ buffered formalin).

\section{RT-PCR}

Total RNA was extracted according to the method of Chomczynski and Sacchi (7). Samples were homogenized in Tri-Reagent (Molecular Research Center, Cincinnati, OH, USA) and RNA was extracted according to the manufacturer's instructions. RNA was quantified by UV absorption and $1 \mu \mathrm{g}$ was reverse-transcribed to prepare complementary DNA (cDNA). Reaction conditions for reverse trancription were: $10 \mathrm{mM}$ Tris $-\mathrm{Cl}, 50 \mathrm{mM} \mathrm{KCl}$, $5 \mathrm{mM} \mathrm{MgCl}_{2}$ (pH 8.3), $50 \mathrm{U}$ Moloney murine leukaemia virus reverse transcriptase, $20 \mathrm{U}$ RNase inhibitor, $1 \mathrm{mM}$ of each dNTP, $2.5 \mu \mathrm{M}$ oligo $\mathrm{d}(\mathrm{T})$ primers (Invitrogen) in a volume of $20 \mu \mathrm{l}$. The reaction was run at $42{ }^{\circ} \mathrm{C}$ for $15 \mathrm{~min}, 99^{\circ} \mathrm{C}$ for $5 \mathrm{~min}$, and $5^{\circ} \mathrm{C}$ for $5 \mathrm{~min}$, and $2 \mu \mathrm{l}$ of the product was used for the PCR.

PCR conditions were: $300 \mathrm{mM}$ Tris $-\mathrm{Cl}, 75 \mathrm{mM}$ $\left(\mathrm{NH}_{4}\right)_{2} \mathrm{SO}_{4}, 7.5 \mathrm{mM} \mathrm{MgCl} 2$ (pH 8.5), $0.25 \mathrm{mM}$ dNTPs, I U Thermus aquaticus DNA polymerase (Life Technologies), and $0.4 \mu \mathrm{M}$ (final concentration) betaglycan primers to a total volume of $50 \mu \mathrm{l}$.

Amplifications were carried out for $1 \mathrm{~min}$ at $94^{\circ} \mathrm{C}$, $1 \mathrm{~min}$ at $53^{\circ} \mathrm{C}$ and $1 \mathrm{~min}$ at $72^{\circ} \mathrm{C}$ for 35 cycles, followed by a final step of $10 \mathrm{~min}$ at $72{ }^{\circ} \mathrm{C}$. Amplification products were visualized on $2 \%$ agarose gel and stained with ethidium bromide.

Betaglycan-specific primers used for amplification by PCR were: 5'-CTGTTCACCCGACCTGAAAT-3' (sense) and 5'-CGTCAGGAGGCACACACTTA-3' (antisense). Computer analysis performed to compare the synthesized oligomers with the human sequences in the gene database of the National Center for Biotechology Information, using BLAST (8), revealed no significant homology among all other genes. Sequence homology among the different oligomers used in the present study was also avoided, thus excluding possible crossreactions. The expected size of the amplified fragment was $502 \mathrm{bp}$; the size of this fragment is specific for RNA, because the primers were localized on different exons. The blank for each reaction consisted of amplifications performed in the absence of reverse transcriptase enzyme.

PCR product identity was confirmed by restriction analysis. The amplified fragment was digested with
Van 91 I (Roche Molecular Biochemicals, Monza, Italy), under the conditions suggested by the manufacturer. The products were separated on $2 \%$ agarose gel and stained with ethidium bromide.

\section{Immunohistochemistry}

Immunohistochemistry was carried out on sections (5 $\mathrm{mm}$ thick) cut from paraffin-embedded samples, mounted on electrostatically charged slides, and dried overnight at $37^{\circ} \mathrm{C}$. Sections were dewaxed, rehydrated and washed in Tris-buffered saline [20 mM Tris-HCl, $150 \mathrm{mM} \mathrm{NaCl}(\mathrm{pH} \mathrm{7,6)].} \mathrm{Tissue} \mathrm{sections} \mathrm{were} \mathrm{heated}$ in a microwave oven twice for $5 \mathrm{~min}$ at $750 \mathrm{~W}$ (EDTA, pH 8) and rinsed in 3\% hydrogen peroxide to block endogenous peroxidase. Slides were incubated overnight at room temperature with the primary antibody, goat anti-human TGF- $\beta$ RIII (R\&D Systems, Abingdon, Oxon, UK) diluted 1:1000, and then incubated with secondary antibody (Dako, Glostrup, Denmark) for $30 \mathrm{~min}$ at room temperature. Harris haematoxylin was used for nuclear counterstaining. A positive reaction was characterized by the presence of granular brown staining in the cytoplasm.

Negative controls consisted of sections in which the primary antibody was replaced by non-immune serum and by using the antibody preadsorbed with the blocking peptide.

\section{Results}

\section{Expression of betaglycan mRNA}

Total RNA extracted from trophoblast, decidua and fetal membranes in the first trimester and at term pregnancy was analysed by RT-PCR. As shown in Fig. 1A, a band corresponding in size to product (502 bp) was obtained from the cDNA of all the samples examined. No amplified fragment caused by DNA contamination was detected in any blank experiment (Fig. 1A). As the 502 bp PCR fragment contained a Van 91 I site, PCR products were submitted to the restriction analysis with Van 91 I, yielding products of the expected size (336 and $166 \mathrm{bp}$ ) (Fig. 1B).

\section{Distribution of betaglycan peptide}

Strong and consistent immunostaining of betaglycan was found in decidual cells obtained from either the first or the third trimester of pregnancy. In decidual vessel walls, the positive stain was restricted to endothelial cells, whereas the other vascular layers (intima and media) were unstained (Fig. 2A,B).

In the placental bed, syncytiotrophoblast, but not cytotrophoblast, cells were intensively stained (Fig. 2C). This was also observed in the terminal villi: syncytiotrophoblast cells were strongly and consistently 

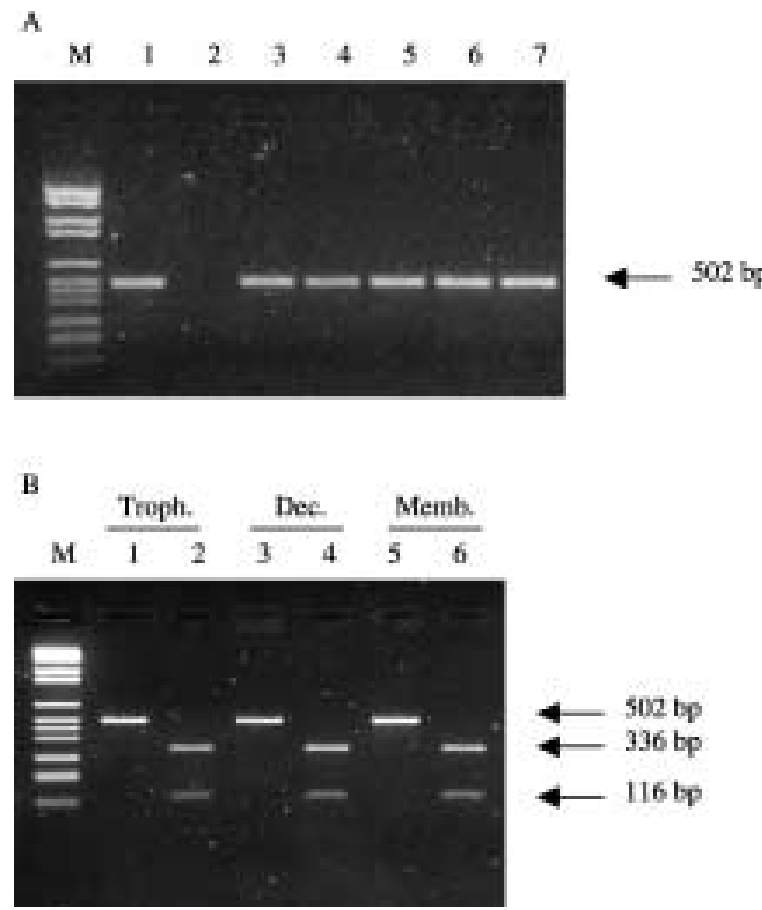

Figure 1 (A) Representative results of RT-PCR analysis of betaglycan mRNA during the first trimester (lane 1: trophoblast; lane 3: decidua; lane 4: fetal membranes) and third trimester (lane 5: trophoblast; lane 6: decidua; lane 7: fetal membranes) of pregnancy. M, molecular mass marker (marker VI, Roche Molecular Biochemicals). Lane 2: blank, consisting of amplifications performed in absence of reverse trancriptase enzyme.

(B) Verification of the identity of the product from placental betaglycan PCR (restriction analysis). Fragment undigested and digested using Van 91 I of decidua, trophoblast and fetal membranes. The sizes of the fragments are indicated. The molecular mass marker (M) is marker VI (Roche Molecular Biochemicals). Troph., trophoblast; Dec., decidua; Memb., fetal membranes.

stained and some stromal cells were positive, but cytotrophoblast cells were completely devoid of stain (Fig. 2D-F). In the villi, endothelial cells were clearly immunostained by betaglycan only in samples collected during the first trimester of pregnancy (Fig. 2D), and not in term placenta (Fig. 2E,F).

Fetal membranes at term showed positivity only in the chorionic connective tissue cells; epithelial amniotic cells were unstained (Fig. 2G).

\section{Discussion}

Betaglycan is a membrane-anchored proteoglycan that has a role in TGF- $\beta$ signaling, functioning as its type III receptor. In the present study, we found that the immunolocalization of betaglycan in gestational tissues (Table 1 ) overlapped with that of TGF- $\beta$, TGF- $\beta$ RI and TGF- $\beta$ RII, which have been demonstrated in the decidua, the syncytiotrophoblast and the chorionic plate, but not in the cytotrophoblast $(4,9)$.
However, betaglycan is also involved in the inhibin $A$ and activin A pathways, as it mediates the passage of inhibin A activity into cells and prevents activin A binding to ActRI, thus antagonizing activin A. Activin A and inhibin A are localized in maternal decidual, amniotic and chorionic cells and in the syncytial layer of placental villi $(4,6,10-12)$, the cytotrophoblast remaining unstained. In the light of these findings, we can conclude that the localization of betaglycan overlaps with that of the TGF- $\beta$ and related receptors, with activin/inhibin $\beta A$ and $\alpha$ subunits, and with activin receptors $(13,14)$.

With respect to placental functions, activin A and inhibin A are differently involved in the control of placental hormonogenesis and differentiation. The addition of activin A to primary cultures of human placental cells increases the production of gonadotropin-releasing hormone (GnRH), progesterone, human chorionic gonadotrophin (hCG) $(4,6,15)$ and oxytocin $(4,6,16)$. In addition, activin $A$ increases the release of prostaglandin $E_{2}$ in human amnionderived cell cultures (12), and has autocrine/paracrine roles in the differentiation of cytotrophoblasts within chorionic villi, by stimulating the outgrowth of cytotrophoblast cells (5). In contrast, inhibin A is not able to affect directly either the secretion of $\mathrm{GnRH}$, progesterone, hCG and prostaglandin $\mathrm{E}_{2}(4,6,15)$, or placental growth and differentiation (5). Thus the lack of inhibin A activity may be attributable to the fact that betaglycan is not expressed by cytotrophoblast and amniotic cells whereas, in contrast, activin exerts an effect because its receptors are localized on the cytotrophoblast and syncytiotrophoblast, and amniotic cells (14).

TGF- $\beta$ also influences placental functions, inhibiting the outgrowth, differentiation (5) and hormonogenesis $(4,17)$ of the extravillous trophoblast. Thus, as betaglycan is expressed by syncytiotrophoblasts but not by cytotrophoblast cells (9), we can hypothesize that the effects of TGF- $\beta$ on the extravillous trophoblast are mediated on the syncytiotrophoblast or, alternatively, through a receptor that has yet to be discovered.

The present study demonstrated immunolocalized betaglycan in endothelial cells of human decidua in the first and third trimesters, but in endothelial cells of trophoblast villi only in the first trimester. Activin/ inhibin receptors (such as ActRI and ActRII) have been immunolocalized in placental endothelial cells mainly at term (14), whereas betaglycan staining has been demonstrated only in tissues of early pregnancy. Because activin A is involved in endothelial proliferation and angiogenesis $(18,19)$, the localization of betaglycan and ActRs in vascular endothelial cells of decidual (13) and villous (14) blood vessels suggests a role for betaglycan in modulating the effect of activin A on vascular adaptations to pregnancy in concert with TGF- $\beta$. Furthermore, although inhibin $A$ is 

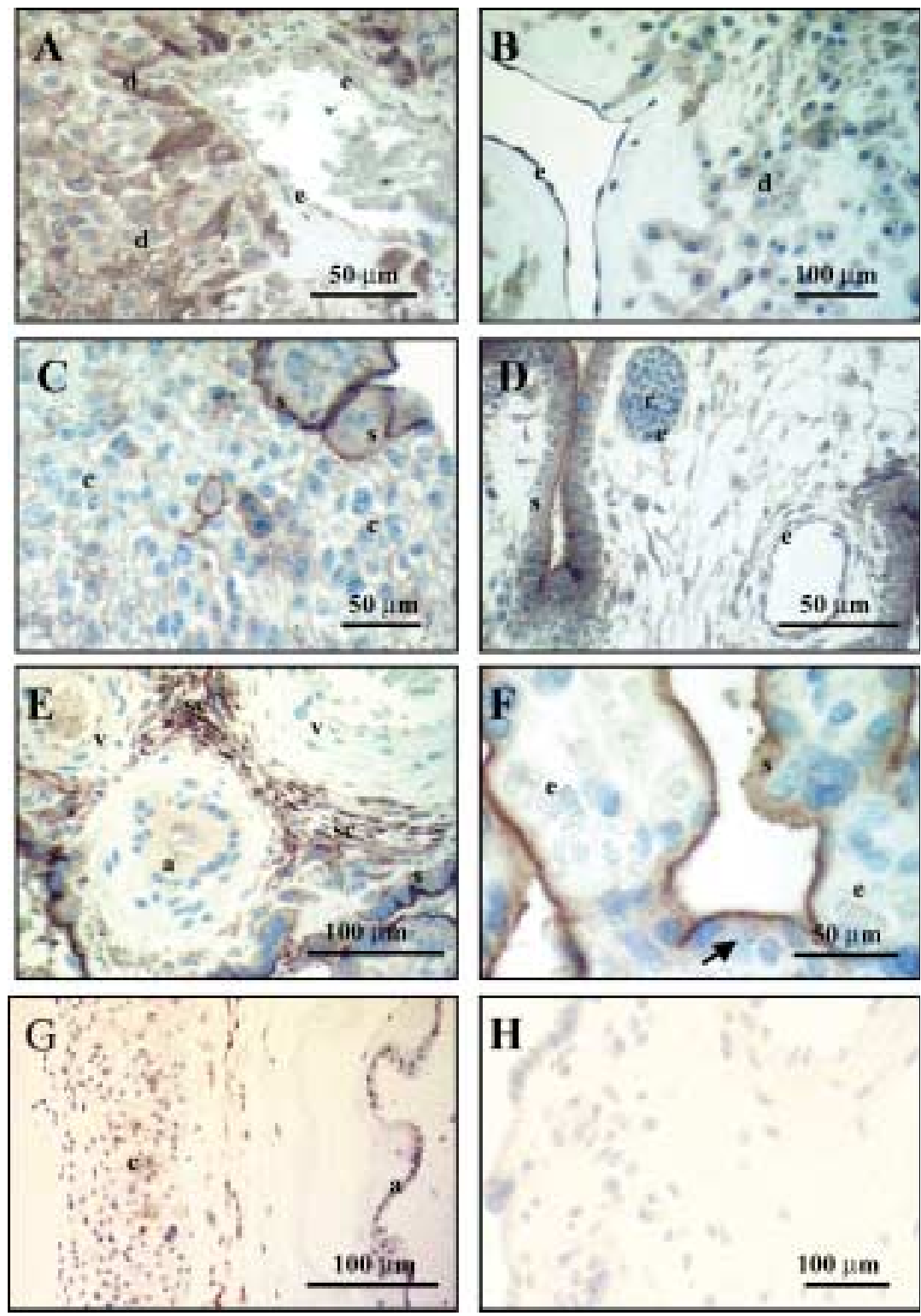

Figure 2 Immunohistochemical staining of betaglycan in the first and third trimesters of pregnancy. (A) First trimester: decidual cells (d) and the thin endothelial layer (e) cells of decidual uteroplacental veins are intensely stained. (B) Term pregnancy: decidual cells (d) and the thin endothelial layer cells (e) of a decidual vein are intensely stained. (C) First trimester of gestation: syncytiotrophoblast (s) but not cytotrophoblast (c) cells are intensely stained. (D) First trimester of pregnancy: syncytiotrophoblast (s) cells around the villus are intensely stained. In addition, inside the villous, the cytoplasm of stromal and endothelial (e) cells of two large vessels [one of which one was full of nucleated red blood cells (r)] are intensely stained. (E) Stem villous at term: stromal (sc) and syncytiotrophoblast (s) cells, but not the wall (intima and media) of either arteries (a) or veins ( $v$ ), are immunostained. $(F)$ Third trimester: intense betaglycan immunostaining was present in syncytiotrophoblast (s) cells of the terminal villi, but vessel walls (e) and cytotrophoblast cells (indicated by the arrow) are unstained. (G) Fetal membranes: chorionic connective tissue (c) but not amniotic epithelial (a) cells are weakly stained. $(\mathrm{H})$ Negative control (villi at term).

without effect on vascular endothelial cell growth (19), TGF- $\beta$, in contrast, is an important modulator of endothelial functions (20). Therefore, betaglycan may serve as mediator of the actions of TGF- $\beta$ and activin A on placental angiogenesis, inhibiting excessive endothelial cell proliferation in human placenta in early pregnancy or modulating the placental vascular permeability that is necessary for implantation of the embryo and placentation.

In conclusion, the present study showed that the expression of betaglycan mRNA and protein in placental vessel walls appears to be dependent on gestational age, thus suggesting different roles of TGF- $\beta$ and activin A during the period of gestation. 
Table 1 Summary of the distribution of betaglycan immunostaining in gestational tissues collected from first and third trimesters of pregnancy.

\begin{tabular}{llc}
\hline Tissue & \multicolumn{1}{c}{ Cell type } & Staining \\
\hline Decidua & Stromal cells & + \\
& Vessels & \\
& Endothelium & + \\
& Intima & - \\
Placental bed & Media & - \\
& Syncytiotrophoblast & + \\
Trophoblast villi & Cytotrophoblast & - \\
& Syncytiotrophoblast & + \\
& Cytotrophoblast & - \\
& Stroma & + \\
& Endothelium & $($ only at first \\
& Intima & trimester of \\
& & pregnancy) \\
Fetal membranes & Epithelial amniotic cells & - \\
& Chorionic cells & - \\
& & + \\
\hline
\end{tabular}

+ , presence of staining; - , absence of staining.

\section{References}

1 Lewis KA, Gray PC, Blount AL, MacConell LA, Wiater E, Bilezikjian LM et al. Betaglycan binds inhibin and can mediate functional antagonism of activin signalling. Nature $2000 \mathbf{4 0 4} 411-414$.

2 Esparza-Lopez J, Montiel JL, Vilchis-Landeros MM, Okadome T, Miyazono K \& Lopez-Casillas F. Ligand binding and functional properties of betaglycan, a co-receptor of the transforming growth factor-beta superfamily. Specialized binding regions for transforming growth factor- $\beta$ and inhibin A. Journal of Biological Chemistry 2001276 14588-14596.

3 Gray PC, Bilezikjian LM \& Vale W. Antagonism of activin by inhibin and inhibin receptors: a functional role for betaglycan. Molecular and Cellular Endocrinology 2002188 254-260.

4 Petraglia F, Florio P, Nappi C \& Genazzani AR. Peptide signaling in human placenta and membranes: autocrine, paracrine, and endocrine mechanisms. Endocrine Reviews 199617 156-186.

5 Caniggia I, Lye SJ \& Cross JC. Activin is a local regulator of human cytotrophoblast cell differentiation. Endocrinology $1997 \mathbf{1 3 8}$ 3976-3986

6 Luisi S, Florio P, Reis FM \& Petraglia F. Expression and secretion of activin A: possible physiological and clinical implications. European Journal of Endocrinology 2001145 225-236.

7 Chomczynski P \& Sacchi N. Single-step method of RNA isolation by acid guanidinium thiocyanate-phenol-chloroform extraction. Annals of Biochemistry 1987162 156-159.
8 Altschul SF, Madden TL, Schaffer AA, Zhang J, Zhang Z, Miller W et al. BLAST and PSI-BLAST: a new generation of protein database search programs. Nucleic Acids Research 199725 3389-3402.

9 Schilling B \& Yeh J. Transforming growth factor-beta(1), -beta(2), -beta(3) and their type I and II receptors in human term placenta. Gynecological and Obstetric Investigation 200050 19-23.

10 Petraglia F. Calza L, Garuti GC, Abrate M. Giardino L, Genazzani AR et al. Presence and synthesis of inhibin subunits in human decidua. Journal of Clinical Endocrinology and Metabolism 1990 71 487-492.

11 Petraglia F, Garuti GC, Calza L, Roberts V, Giardino L, Genazzani AR et al. Inhibin subunits in human placenta: localization and messenger ribonucleic acid levels during pregnancy. American Journal of Obstetetrics and Gynecology 1991165 750-758.

12 Petraglia F, Anceschi MM, Calza L, Garuti GC, Fusaro P, Giardino $\mathrm{L}$ et al. Inhibin and activin in human fetal membranes: evidence for a local effect on prostaglandin release. Journal of Clinical Endocrinology and Metabolism 199377 542-548.

13 Jones RL, Salamonsen LA, Zhao YC, Ethier JF, Drummond AE \& Findlay JK. Expression of activin receptors, follistatin and betaglycan by human endometrial stromal cells; consistent with a role for activins during decidualization. Molecular Human Reproduction $20028363-374$.

14 Schneider-Kolsky ME, Manuelpillai U, Waldron K, Dole A \& Wallace EM. The distribution of activin and activin receptors in gestational tissues across human pregnancy and during labour. Placenta 200223 294-302.

15 Petraglia F, Vaughan J \& Vale W. Inhibin and activin modulate the release of gonadotropin-releasing hormone, human chorionic gonadotropin, and progesterone from cultured human placental cells. PNAS $1989865114-5117$.

16 Florio P, Lombardo M, Gallo R, Di Carlo C, Sutton S, Genazzani AR et al. Activin A, corticotropin-releasing factor and prostaglandin F2 alpha increase immunoreactive oxytocin release from cultured human placental cells. Placenta 199617 307-311.

17 Song Y, Keelan J \& France JT. Activin-A stimulates, while transforming growth factor beta 1 inhibits, chorionic gonadotrophin production and aromatase activity in cultured human placental trophoblasts. Placenta 199617 603-610.

18 Kozian DH, Ziche M \& Augustin HG. The activin-binding protein follistatin regulates autocrine endothelial cell activity and induces angiogenesis. Laboratory Investigation 199776 267-276.

19 McCarthy SA \& Bicknell R. Inhibition of vascular endothelial cell growth by activin-A. Journal of Biological Chemistry 1993268 23066-23071.

20 Baird A \& Durkin T. Inhibition of endothelial cell proliferation by type beta-transforming growth factor: interactions with acidic and basic fibroblast growth factors. Biochemistry and Biophysics Research Communications 1986138 476-482.

Received 4 April 2003

Accepted 22 July 2003 